\title{
Joint Household Biogas CDM Mode Advancement Analysis
}

\author{
Fan Yang \\ North China Electric Power University \\ Baoding,Hebei,China \\ 406624985@qq.com.
}

\begin{abstract}
We take research of straw-gas joint household gas project in Hebei Qingxian for example. First, based on the experience of Danish concentrated methane gas, we use the method of cost-benefit analysis so as to carry on comparative analysis of its economic feasibility. Second, we standardize the environmental impact, analyzing the pollution and hazards caused by burning straw before. The results show that the introduction of Clean Development Mechanism (the Clean Development Mechanism, CDM) of the joint household biogas project, has a great advancement in the economic and ecology. So we can affirm the joint household biogas has an important value and significance for rural energy conservation and emissions reduction.
\end{abstract}

Keyword-Staw biogas project; CDM mode; Assessment;Cost-benefit analysis;Emissions reduction.

\section{BASIC SITUATION OF CASE}

Taking on the spot investigation in Qing County, Hebei Province as example, we analyze Joint household biogas supply mode, and introduce Clean Development Mechanism (CDM)[1]. At last, we explore the suitable joint household gas supply mode in rural areas of China. So as to achieve the purpose of energy save, biogas projects efficiency improvement, and environment protect.

Qing county, Hebei province Joint household biogas[2] is mainly stars from DongYao village, Geng GuanTun Village, and implement enterprise production of the biogas, large-scale gas supply, and commercial operation. " Centralized station, joint village supply ",this method makes the rural areas to eliminate the straw burning. In Qing county, though large-scale gas supply project one-time investment is a bit huge, difference with household biogas digester average costs is not huge, even lower than the construction of digester. Due to the concentration of biogas investors and business model changes, allowing farmers to get cheaper gas, and more convenient to use. Compare to single household biogas, it can avoid management and maintenance problems, so it is more attractive to farmers. In terms of life, real life of centralized biogas projectis is much longer than household biogas.

\section{EXPERIENCE REFERENCE}

Overseas research for joint household biogas is earlier than in China, Sòren Tafdrup(1994) analyzes its benefits on agriculture and natural environment in Denmark[3]. He thought that biogas was cheaper, more environmental protection and low consumption, but it requires the public investment to solve its funding problems, to promote its use for long. Orrit Gosens (2012) analyzes that biogas persistent effect is beneficial to environmental protection and energy supply[4], but its subsequent development, cannot leave the support of the government policy and funding. Guizhen $\mathrm{He}$ (2013) compares the centralized(joint) to decentralized(household-type), their economic and technical value and sustainability are different. So he thinks the construction and utilization of biogas system should consider the local natural conditions, economic and social, then to determine its which final form should be taken. Hongyan $\mathrm{Lu}$ (2013) after the on-the-spot investigation, she thinks joint household biogas can not only protect local environment and climate, but also supply fertilizer can be recycled, what's more, this projects influence benefit among farmers, investment companies and technology companies. When developing to a certain extent, it needs policy guidance to develop the industry.

Our joint household biogas rise later than household-type biogas, part of scholars studied household biogas aiming at the existing problem of it. Changwei Li (2010) points out the need to promote joint household biogas after studing Ci county, Hebei province. Dancheng $\mathrm{Ni}$ (2011) analyzes the feasibility of implementing joint household biogas from three aspects of technology, society and economy, he thinks its scale degree is higher than traditional household biogas. Further more, its channels of funding sources is various, management is convenient, and the farmers acceptance degree is high, so it has a wide promotion market. 


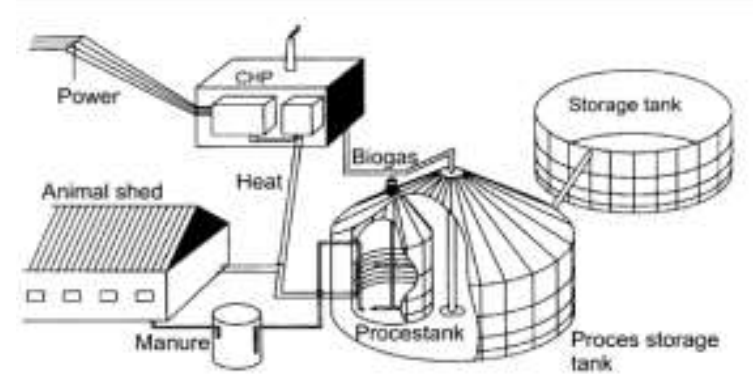

\section{ECONOMIC ANALYSIS}

Geng GuanTun Village Locates in the eastern part of Hebei central plains, terrain is mainly plain, less mountainous so it is relatively flat. The village is in an area under temperate continental monsoon climate, has significant precipitation. Average annual temperature is $12.1{ }^{\circ} \mathrm{C}$, annual sunshine is 2769.8 hours, frost-free period is 180 days, average annual rainfall is $618 \mathrm{~mm}$, with good nature, climate, geology, hydrology conditions which are suitable for building large-scale biogas projects.

\section{A. Initial investment and operating costs}

At present, fifteen 300 to 2000 cubic meters of large steel plate welding fermentation tank and propane tanks have already constructed in four village in Qing County, 5500 farmers, and local food factory can enjoy the convenience of heating supply. After years of trial, demonstration and construction, straw methane gas supply system project begun to take shape, produced results, which has achieved a certain economic, social and ecological benefits. Moreover, in today's world to promote the development of recycling economy and encourage energy conservation, building the CDM background, pure straw gas engineering technology has good prospects for development[5].

TABLE I. COST OF PRODUCTION

\begin{tabular}{rlc}
\hline Type & \multicolumn{1}{c}{ Unit Price } & Total Price \\
\hline Raw materials & 300 yuan/ton & 219000 yuan \\
\hline $\begin{array}{r}\text { Straw collection\& } \\
\text { processing power }\end{array}$ & $0.1 \mathrm{yuan} / \mathrm{m}^{3}$ & 36500 yuan \\
\hline Operating wages & 800 yuan/person/month & 38400 yuan \\
\hline $\begin{array}{r}\text { Equipment } \\
\text { maintenance }\end{array}$ & ----- & 20000 yuan \\
\hline
\end{tabular}

Before 2008, per household needs to invest around 3500 yuan in a more than 500-household scale project. Due to the design standard improvement, per household needs to invest around 5500yuan in a more than 1000-household scale biogas project. We take 1000 -household scale as example, remove the cost such as research, preliminary design, unpredictable cost, we estimate the overall investment is 5.31 million yuan. The main investment spending in the following construction: fermentation tanks, storage tanks, transmission and distribution systems in the station, purification systems, fire systems, heating systems, automation systems, the total is 2.8 million yuan; civil engineering 1.1 million yuan; transmission and distribution network 1.1 million yuan; survey, design, budget, supervision 180,000 yuan; gas stove 130,000 yuan[6]. The cost distribution is as following table:

TABLE II. COST DISTRIBUTION

\begin{tabular}{ll}
\hline \multicolumn{1}{c}{ Construction } & \multicolumn{1}{c}{ Cost } \\
\hline Facilities & 2.8 million yuan \\
Civil engineering & 1.1 million yuan \\
Transmission and distribution network & 1.1 million yuan \\
Survey, design, budget, supervision & 180,000 yuan \\
Gas stove & 130,000 yuan \\
TOTAL & 5.31 million yuan \\
\hline
\end{tabular}

In respect of (predictable) engineering operation cost, with $1000 \mathrm{~m}$ after biogas project as an example, the total production cost $_{3}$ is RMB 313900 / year, average cost is RMB $0.86 / m^{3}$.

\section{B. Direct economic benefits}

We investigated different civilian energy prices in Qing county, and took the most common type of 1000 cubic meters of biogas project as example, calculated the direct profit of biogas station. The profit is mainly divided into biogas profit and residues profit. 


\begin{tabular}{ll}
\hline Coal & $\begin{array}{l}\text { From the calorific value, biogas and coal are the same. From stove thermal efficiency } \\
\text { the former is three times the latter. And coal stove need specialized management, } \\
\text { dealing with flameout is troublesome, so coal has no advantage. }\end{array}$ \\
\hline Natural gas & When the gas price is higher than 3.2 yuan $/ \mathrm{m}^{3}$, straw biogas is much cheaper. \\
\hline LPG & Compared with the same calorific value of LPG, biogas can save 2.9 yuan per cubic \\
& meter. Each household with biogas about $1 \mathrm{~m}^{3}$ every day, then they can save about \\
& 10000 yuan per year.
\end{tabular}

In addition, we also compared the saving costs for residents to use biogas energy than any other. Liquefied petroleum gas(LPG) market price is 9 yuan $/ \mathrm{kg}$, honeycomb briquet is 0.45 yuan/piece, electricity is 0.52 / degree. Therefore, biogas is $1.6 \mathrm{yuan} / \mathrm{m}^{3}$, it is more cheaper obviously. The concrete value can be seen in the following table.

TABLE IV. COMPARED WITH OTHER ENERGY

\begin{tabular}{ll}
\hline Biogas profit & Biogas price is 1.6 yuan $/ \mathrm{m}^{3}$, gas station profit is about $0.7 \mathrm{yuan}^{\prime} \mathrm{m}^{3}$. \\
& Annual profits is 255,500 yuan. \\
\hline biogas residues profit & Station produces biogas residues about $1200 \mathrm{~m}^{3}$ annually, unit selling price is \\
& 20 yuan $/ \mathrm{m}^{3}$. Annual profits is 24,000 yuan. \\
\hline TOTAL & 279,500 yuan annually. \\
\hline
\end{tabular}

With the steady growth of China's rural residents income, rural energy demand will continue to rise. According to the ministry of agriculture science and technology education department and energy environmental protection technology development center statistics show that in 2009, the Chinese farmers per capita energy consumption has reached $774.3 \mathrm{~kg}$ of standard coal, up $66.7 \%$ from 2000. Including the use of fossil fuels such as coal, oil continues to grow, 2009 petrochemical energy have accounted for $44 \%$ of the rural life energy, second only to the traditional biomass energy such as straw and firewood proportion (table 3). Increase of farmers' demand for energy not only aggravates the strain of the commercial energy supply and demand situation, but also increased the burden on farmers. At the same time, give priority to with straw, firewood and other traditional biomass energy structure of rural life, vegetation damage, is not conducive to ecological environment protection. Biogas as a renewable clean energy, can replace traditional biomass (straw and firewood, can replace coal commodities such as energy. Development of rural biogas, optimize the structure of rural energy consumption, to reduce the pressure on China's energy and promote rural environmental protection is of great significance.

\section{Additional economic benefits}

The application of joint household biogas, makes transformation of science and technology strength increase rapidly. The economic value of straw is uncovered, not only increases income for farmers, but also solves the problem of field straw accumulation .

What's more, biogas has significant additional economic benefits[8]. After purification, biogas can break down the natural gas and carbon dioxide, natural gas can be directly used in automobile gas and industrial gas, carbon dioxide can be used for industrial and shed room vegetables fertilizing, etc, so as to produce a greater benefit. When biogas slurry and residues though processing[9], they will become green organic fertilizer which are rich in $\mathrm{N}, \mathrm{P}, \mathrm{K}$ and the 40 many kinds of trace elements. per cubic meter of residues can increase the added value of 350 yuan above.

Straw after fermentation to produce biogas, residual output of renewal, the biogas slurry is pollution-free organic fertilizer, used in agricultural production, can produce pollution-free organic food, and plant straw produced at the same time. And straw for the production of biogas, realize the benign cycle of matter and energy, really realize the circulation economy, energy conservation and emissions reduction, can generate considerable economic benefits and environmental benefits. 
Biogas fermentation can produce a large number of renewal biogas slurry, particularly partnerships biogas renewal of the biogas slurry has the characteristics of continuity, a large number of sex, concentrated, if not handled properly can cause secondary pollution to environment. The renewal of biogas slurry is relatively mature fat with pattern has the following kinds: one is the water use, the second is as a foliar fertilizer application, three is the renewal after biogas slurry separation will renewal made into organic fertilizers. The experiment proves that the renewal organic fertilizer nutrients contained, with fully exploiting the stability and long, organic matter content, increase soil organic matter and improving soil physical and chemical properties. Can not only supply crops, but also provide soil microbial nitrogen, phosphorus, potassium and other nutrients, as well as vitamins and growth hormone. After renewal organic fertilizer applied into, can by enhancing the soil enzyme activity, promoting the transformation of nutrients, thus increasing crop nutrition.

Mature technology, at present, the renewal biogas slurry organic fertilizer industry development partnerships biogas producing renewal in the biogas slurry organic fertilizer, on the one hand, to prevent the renewal biogas slurry direct emissions cause secondary pollution, on the other hand can increase the economic income. Farmers use renewal biogas slurry organic fertilizer can improve the agricultural product added value to increase income, protect the agriculture ecological environment and promote sustainable development of agricultural production.

\section{ECOLOGICAL BENEFIT ANALYSIS}

With the improvement of living standards, farmers' demand of straw goes down, this makes the rural straw usually adopt the method of burning process, which causes serious air pollution and is harm to human health. Burning straw, $\mathrm{SO}^{2}, \mathrm{NO}^{2}$ and $\mathrm{PM} 10$ in atmosphere, these three pollution index reaches its peak value. In particular, the concentration of $\mathrm{SO}^{2}$ is two times as usual, $\mathrm{NO}^{2}$ and PM10 concentration is 3 times higher than normal.

$1000 \mathrm{~m}^{3}$ scale straw biogas project consumes about 730 tons of straw, with an annual output of $365000 \mathrm{~m}^{3}$ of gas and biogas residues $1500 \mathrm{~m}^{3}$. Through the use of biogas, each household generally can reduce burning straw 10 kilograms every day, then 1000 households can reduce direct burning straw 3650 tons each year, they can save 260 tons of standard coal. $\mathrm{CO}^{2}$ emission reduces 676 tons, $\mathrm{SO}^{2} 2.21$ tons, nitrogen oxides 1.92 tons, dust 0.31 tons. In Hebei province, it is not only beneficial to reduce air pollution, improve the fog and haze effectively, but also conducive to curb soil and water loss, protect the ecological environment[10]. If straw biogas can constantly gain popularity, even in the industrial developing replace coal, oil, natural gas, etc., , the ecological environment across the country will be greatly improved.
According to relevant statistics show that by using biogas, generally every day can reduce burning straw $5 \mathrm{~kg}$, 1000 households can directly reduce the burning straw 1825 tons per year, you can save 206 tons of standard coal, to reduce emissions $\mathrm{CO} 2260$ tons, $\mathrm{SO} 22.21$ tons, significantly improve the living environment, effectively consolidate the role of ecological construction. After biogas purification, can be a natural gas and carbon dioxide to a wider range of applications, more improve the efficiency and use scope of biogas. Renewal biogas slurry into organic fertilizer to promote pollution-free agricultural production and improve agricultural products quality is very good also, at the same time also can promote the farmers' income. In addition, through developing biogas technology application promotion, is a good way to solve the farmers' daily energy consumption is too big and parts of rural life energy shortage problem. To improve farmers' living standard, improve rural environmental sanitation.

And joint household biogas engineering is able to meet the two outstanding problems faced in the new rural construction. One is to achieve high quality clean energy supply of the farmer.Medium temperature fermentation, is not affected by temperature, makes up for the problem of household biogas in winter can't normal gas, meet the needs of farmers to have stable gas supply. Comparative advantage price, replacement of the commodity energy such as natural gas, liquefied gas, electricity. At the same time, solved the problem of the straw, coal cannot go upstairs, to improve the quality of the farmers can use. The second is to realize the rural environment comprehensive improvement. Straw heap of the place, human and animal waste, living garbage and sewage discharge, the rural environment is considered the main pollution sources. Through the project construction, to realize harmless treatment and resource utilization, has created a clean environment for the new countryside.Take 1000-household as example,3.5 population per household in average, digestible in straw, waste, living garbage and sewage of more than 02000 tons, section BiaoMei about 652 tons, 1695 tons of carbon dioxide, 127700 tons of water saving.

\section{REFERENCES}

[1] Yanfei Li. Straw Biogas Project Operation Pattern and Managerial Experience[J]. Agricultural Project Technology(New Energy), 2010,08:9-13.

[2] Chunguo Wang, Jing Zhang, Yanfei Li.Straw Biogas Centralized Gas Supply Status Analysis in Qing County,Hebei Province[J]. Agricultural Project Technology(New Energy), 2014,05:15-18.

[3] Brian Vad Mathiesen,Henrik Lund,Kenneth Karlsson.100\% Renewable energy systems, climate mitigation and economic growth[J].Applied Energy,2011,88(2):488-501.

[4] Angelidaki ,L. Ellegaard . Codigestion of Manure and Organic Wastes in Centralized Biogas Plants[J]. Applied Biochemistry and Biotechnology,2003,109,(1-3):95-105.

[5] Huibin Li,Kai Zhao,Yue Liu,Ting Wang, Chunxiang xue. Development of Straw Biogas Joint Household Supply in Hebei[J].China Biogas,2011,29(6):43-44,27. 
[6] Hongyan Wang,Yuyun Bi,Daolong Wang. Straw Biogas Centralized Gas Supply Economy Feasibility Analysis and Simulation[J]. China Biogas,2014,32(1):75.

[7] Pan Ke,Qili Zhu,Qichun Hu. Rural Partnerships Biogas Plans and Technical Analysis[J]. China Biogas,2010,28(3):28-29.

[8] Cheng Xu,Liang Jingguang,Zheng Hehengshou,et al. Tapping of China's biogas industry and its perspective[J].Transactions of the case, 2010,26(5):1-6.
[9] Zheng Ge, Zhang Quanguo. Review on biogas upgrading technology for producing biomethane[J]. Transactions of the Chinese Society of Agricultural Engineering (Transactions of the CASE),2013,29(17):1-8.

[10] Kuang Jing,Zhang Enhe,Chen Bingpu. Evaluation of Economic and Environmental Benefits of Joint Household Biogas Project[J]. Chinese Agricultural Science Bulletin,2011,27(04):401-405 